\title{
The evaluation of ash content in grass biomass used for energy production
}

\author{
R. Platače \& A. Adamovičs \\ Latvia University of Agriculture, Institute of Agrobiotechnology, Latvia
}

\begin{abstract}
One of the greatest problems in the production of bioenergy is related to the cultivation of high-quality perennials having a particular chemical content. The yield and chemical content thereof is largely influenced by fertilisers: their types and norms, especially by ones used during the growing period. The production of heat requires plants bringing high biomass yield, having high combustion ability, high heat output and low ash content. Perennial grasses are essential for the agricultural production sector in Latvia. The nature and extent of winter damage on grasslands highly depends upon the climatic conditions, moreover it influences both persistency and yield. Scientists have found out that plant biomass is one of the best sources that may be used for the production of solid biofuels. Ash is one of the main indicators in heat production, since higher content thereof causes problems in the automatic combustion process. Analysis of the ash content among all the three grass plants shows the lowest indicator in timothy, followed by meadow fescue, and festulolium. Analysis of the ash content depending on the fertiliser applied was conducted as well, and it indicated that festulolium, timothy, and meadow fescue effectively react on the treatment with fertilisers.

The data acquired shows that biomass has a high ash content; therefore it could be useful to produce pellets from grass plant biomass, mixing it with wood, which would reduce ash content (one of the key problems in the combustion process causing problems for the heating system).

Keywords: festulolium, timothy, meadow fescue, nitrogen fertilizers, ash.
\end{abstract}

\section{Introduction}

The European Union (EU) is striving to reduce influence wielded by the climate changes and to develop common energy policy within the whole Community. The aim of this policy is $20 \%$ of the total EU energy consumption from 
renewable sources till 2020 (in 2005-8.5\%). Currently in Latvia 32\% of total energy are produced from renewable sources, while in 2020 it should reach $40 \%$ (2009/28/EC) [1]. The high targets set in Europe for the production of biofuels will require high energy yields and efficient use of available agricultural land [2]. Use of biomass in energy production is a precondition crucial to avoid ecological disasters in future and to compensate increasingly growing shortage of fossil energy resources [3]. Alternative and renewable fuel sources, such as solar, geothermal, wind, and biomass, have the potential of reducing greenhouse gas emissions [4], avoid environmental impacts associated with fossil fuel extraction, such as mountaintop removal, oil spills, and acid deposition, and can increase energy independence [5]. Biomass is very promising, because it can be converted into liquid fuel, burned directly to produce heat, or combusted to generate electricity [6]. Current estimates suggest that globally the combination of all biomass sources may provide $15-25 \%$ of the world's energy demand [7]. EU politics and economy encourage utilisation of grass plants for the production of energy sources, namely biofuel and biogas. Economic viewpoint suggests that grass species producing high and stable biomass yield, ones that are perennial and permanent, modest in respect to growing conditions, as well as resistant to cold, drought and other adverse environmental factors are the most suitable for this purpose.

One of the most topical problems encountered in Latvia agriculture is the acquisition of high-quality perennial grass plants with definite chemical content, ensuring that they may be used for the production of bio-energy - solid fuel (pellets, briquettes).

Within the territory of Latvia grass biomass currently is considered to be one of the alternative sources for biomass production in Baltics and Northern Europe. Grass plants are characteristic with persistence to local climatic conditions and high biomass yield from 1 ha.

Grass plants are significant group of natural grasses and arable crops very suitable for agro-climatic conditions of Latvia. The main aim of cultivation thereof lies in acquiring possibly higher valuable biomass that may be used for the production of bioenergy [8].

Production longevity and cold tolerance of grass frontispieces ensures multiannual and stable production of biomass under less favourable climatic conditions, thus reducing also production costs and saving resources. Grass plants (festulolium, timothy, meadow fescue) excel in productivity, fast development, high yield, resistance to diseases and unfavourable climatic conditions, durability in dry weather conditions as well as comparatively high and low temperatures $[9,10]$.

Effective use of nutrients is of a great significance for sustainable agricultural production. Sufficient amount of nutrients ensures favourable conditions for long-term and stable use of soil resources and high crop yield. Fertilisers along with the climatic and soil conditions are vital for productivity and yield quality. Nitrogen $(\mathrm{N})$ quantities, use efficiency as well as energy input are important for environmental impact and production of energy crops. Nitrogen fertilisers increase yield and quality of grass plants notably, as soil has high humus content 
and low nitrogen supply. Several researches indicate that higher norms of nitrogen fertilisers affect yield of grass dry matter [11-13]. Nitrogen is significant for plant life processes and thus also for the yield of crops.

Under the specific climatic conditions of Latvia, heat supply is significant part of the energy sector, consuming approximately $62 \%$ of the total fuel volume. Heat power industry allows acquiring local renewable resources with the highest efficiency. At the end of 2010, installed electric capacity of biomass and biogas power plants of all types in Latvia comprised $22 \mathrm{MW}$.

Heat production requires plants with high biomass yield, combustion ability, heat output and low ash content. Content of ash characterises amount of the noncombustible minerals in fuel. Ash consists of minerals that remain as fuel is burnt, i.e., those are inorganic substance [14]. The content thereof is one of the key indicators that in line with standard DIN 51731 should not exceed 1.5\%. Higher ash content causes problems with combustion automation, moreover thermal capacity of such pellets is by $600-1000 \mathrm{~kJ} / \mathrm{kg}$ lower (e.g., thermal capacity of bark briquettes with ash content $14 \%$ comprises $16554 \mathrm{~kJ} / \mathrm{kg}$, while DIN 51731 sets that thermal capacity should reach at least $17500 \mathrm{~kJ} / \mathrm{kg}$ ) [15]. Although ash is not a pollutant, it is a remnant of combustion that must be removed. High ash contents may discourage household consumers as well as industrial users of biofuels, and it may affect power plants by corroding and fouling machinery. Ash content in biomass depends on various factors, e.g., plant species: switchgrass $-8.3 \%$, giant reed $-6.1 \%$, miscanthus $-2.3 \%$, cardoon $-17.4 \%$, wood pellets $-0.50 \%$ [16]. Whereas ash content in wood fuels does not exceed $1.4 \%$, in peat pellets and briquettes it varies between $1.27 \%$ and $5 \%$. It may be explained by the fact that peat content varies rather greatly and may contain various mineral substances. Ash content in cereal straw among various species varies between $5 \%$ and $8 \%$. Ashes from different sources probably could be used as fertilizer or component for multi component fertilizers [17]. Ash is full of potassium $(\mathrm{K})$, calcium $(\mathrm{Ca})$, sulphur $(\mathrm{S})$, as well as chlorine (Cl) and silicon (Si) [18]. All elements mentioned are significant for plants, while ash commonly is more often used as a fertiliser full of $\mathrm{K}$ and $\mathrm{Ca}$. $\mathrm{Ca}$ is the second most important microelement after N. It is advisable to use ach on more acidic soils, as it increases $\mathrm{pH}$ of the soil. Research has shown that ash leave positive effect on soil structure, aeration, water maintenance and cation exchange capacity.

The aim of this research is the measuring and characterisation of grass biomass ash content depending on the types and norms of fertilisers.

\section{Materials and methods}

The field trial was carried out during 2011-2012 in research and study farm "Peterlauki" $\left(56^{\circ} 53^{\prime} \mathrm{N}, 23^{\circ} 711^{\prime} \mathrm{E}\right)$ of the Latvia University of Agriculture, in the sod calcareous soils pHKCl 6.7, containing available for plants $\mathrm{P} 52 \mathrm{mg} \mathrm{kg}^{-1}$, $\mathrm{K} 128 \mathrm{mg} \mathrm{kg}^{-1}$, organic matter content 21 to $25 \mathrm{~g} \mathrm{~kg}^{-1}$ in the soil. The field test fertiliser norms applied were following $\left(\mathrm{kg} \mathrm{ha}^{-1}\right)$ : N0P0K0 (control) $\mathrm{P}_{2} \mathrm{O}_{5}-80$, $\mathrm{K}_{2} 0-120$ (F - background), F + N30, F + N60, F + N90, F + N120 (60 + 60), 
$\mathrm{F}+\mathrm{N} 150(75+75), \mathrm{F}+\mathrm{N} 180(90+90)$, vermicompost $-10 \mathrm{t} \mathrm{ha}^{-1}$. Seed sowing norm -1000 germinant seeds per $1 \mathrm{~m}^{2}$; usage type: mowing two-three times.

The study will cover research of following energy crops to be used for the fuel (pellet) production: culmiferous plants (Poaceae): festulolium (x Festulolium Asch. \& Graebn.) var. 'Vetra'; meadow fescue (Festuca pratensis Huds.); timothy (Phleum pratense L.).

Research conducted in Latvia and Lithuania found that all these species are suitable for production of bioenergy, as they are perennial and highly productive [19].

Ash content in different composition samples was found out in the agricultural scientific laboratory for agronomic analyses of the University of Latvia in compliance with the ISO 5984:2002/Cor1:2005 standard. For each sample three parallel experiments were carried out, repeating each tested combination three times. The correlations were analyzed as linear or polynomial regressions, and graphs were made using MS Office program Excel.

\section{Results and discussion}

The results acquired show that the biomass of all festulolium, timothy, and meadow fescue have high ash content. Slightly lower ash content was observed for festulolium (from $6.57 \%$ to $7.78 \%$ ), while in timothy it was slightly higher (from $4.99 \%$ to $7.02 \%$ ), and in meadow fescue (from $6.05 \%$ to $6.88 \%$ ), fig. 1 .
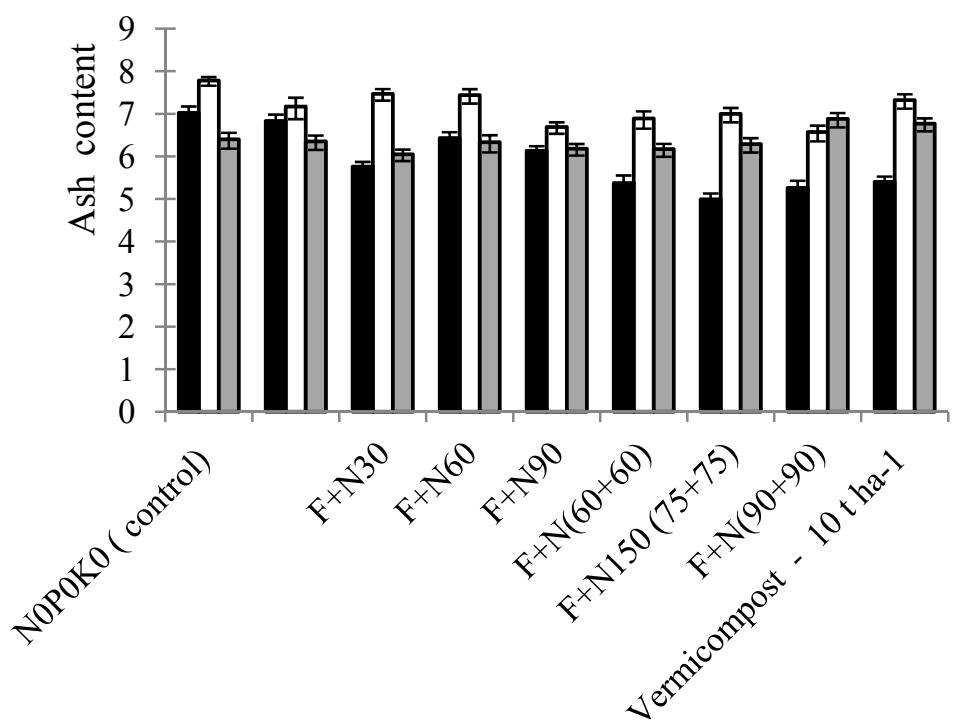

Dimothy $\quad$ TFestulolium $\quad$ Meadow fescue

Figure 1: Ash content in timothy, festulolium, and meadow fescue depending on fertiliser type and norm. 
The highest ash content was recorded in festulolium with fertiliser N0P0K0 (control) $-7.78 \pm 0.06 \%$, while in timothy with fertiliser N0P0K0 (control) $7.02 \pm 0.11 \%$, and in meadow fescue with fertiliser $\mathrm{F}+\mathrm{N}(90+90)-$ $6.88 \pm 0.10 \%$; whereas the lowest ash content of festulolium was observed in samples treated with fertiliser $\mathrm{F}+\mathrm{N}(90+90)-6.57 \pm 0.11 \%$, in timothy samples with fertiliser F $+\mathrm{N} 150(75+75)-4.99 \pm 0.10 \%$, and in meadow fescue samples with fertiliser $\mathrm{F}+\mathrm{N} 30-6.05 \pm 0.08 \%$.

To find out the correlation between the ash content in grass plant biomass and $\mathrm{N}$ fertiliser, a correlation analysis was carried out (fig. 2, fig. 3, and fig. 4).

In the case of fig. 2 there is a close, negative linear correlation $(\mathrm{r}=-0.84, \mathrm{p}<0.05)$ between the timothy biomass ash content and $\mathrm{N}$ amount in fertiliser. As $\mathrm{N}$ content is increased, ash content in biomass reduces; thus higher the $\mathrm{N}$ content in fertiliser, the lower ash content in slag.

In the case of fig. 3 there is a medium close, negative linear correlation $(\mathrm{r}=-0.73, \mathrm{p}<0.05)$ between the festulolium biomass ash content and $\mathrm{N}$ amount in fertiliser. As $\mathrm{N}$ content is increased, ash content in biomass reduces; thus higher the $\mathrm{N}$ content in fertiliser, the lower ash content in slag.

In fig. 4 there is a medium close, negative linear correlation between the meadow fescue biomass ash content and $\mathrm{N}$ fertiliser norm $(\mathrm{r}=-0.57, \mathrm{p}<0.05)$; thus as $\mathrm{N}$ content in meadow fescue biomass grows, the ash content decreases.

The lowest ash content was observed in timothy samples treated with vermicompost $(5.40 \pm 0.09 \%)$. Notably higher ash content $(\mathrm{p}<0.05)$ was recorded when samples were not treated with fertilisers $(7.02 \pm 0.11 \%)$; while application of fertilisers leads to ash content $(5.82 \pm 0.17 \%)$ that does not notably differ from the one in timothy samples grown in soil fertilised with vermicompost, as well as from timothy samples not treated.

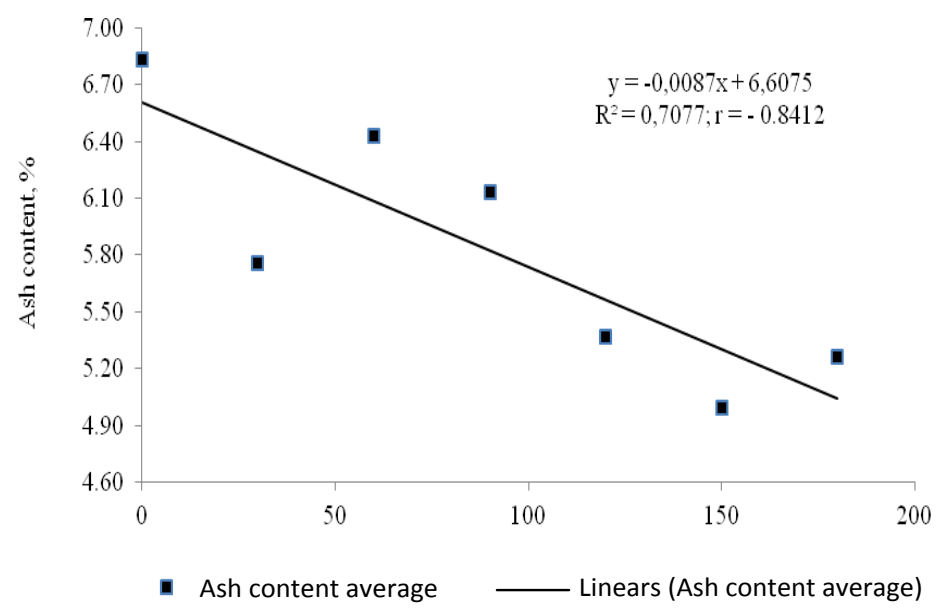

Figure 2: Average ash content in timothy biomass depending on $\mathrm{N}$ fertiliser norm. 


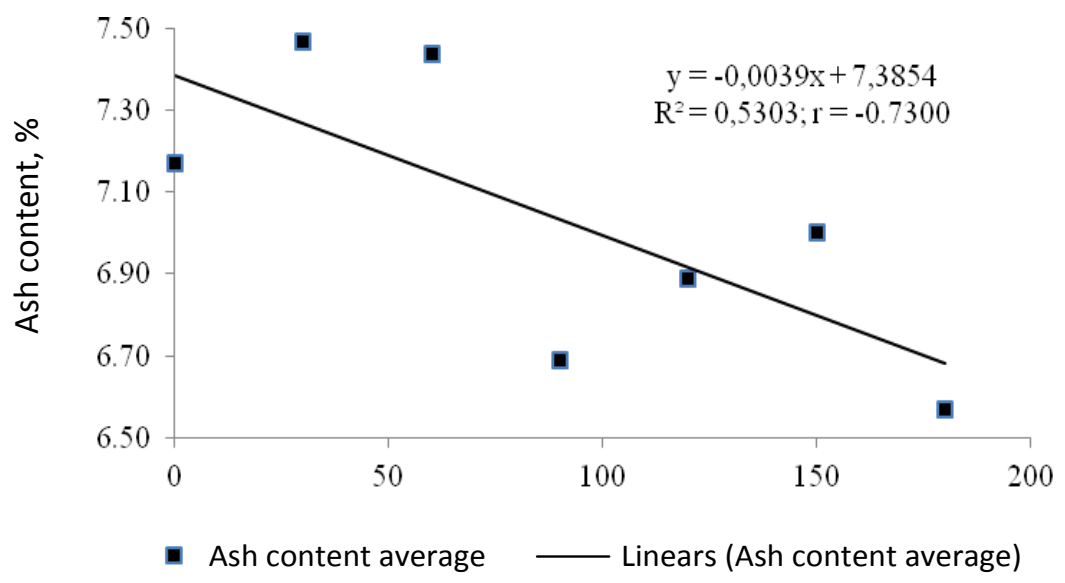

Figure 3: Average ash content in festulolium biomass depending on $\mathrm{N}$ fertiliser norm.

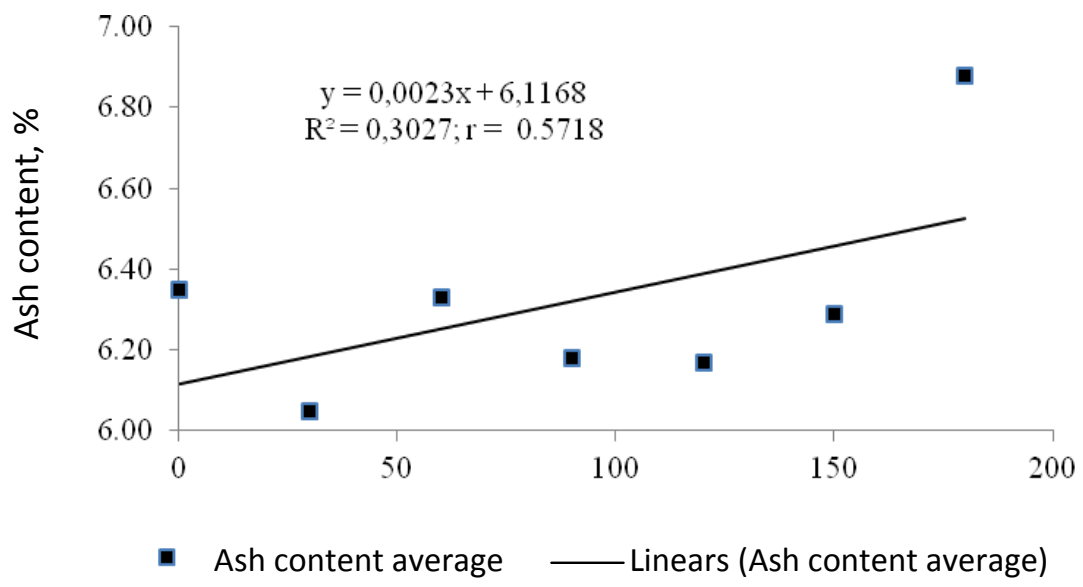

Figure 4: Average ash content in meadow fescue biomass depending on $\mathrm{N}$ fertiliser norm.

Looking at fig. 5, an opposite trend may be observed in the festilolium samples: highest ash content was recorded in samples not treated with fertilizer $(7.78 \pm 0.06 \%)$, notably lower $(\mathrm{p}<0.05)$ in samples. Another tendency may be seen in meadow fescue samples: highest ash content was recorded in samples treated with vermicompost $(6.77 \pm 0.09 \%)$, notably lower $(\mathrm{p}<0.05)$ in samples 
not treated and treated with $\mathrm{N}(6.32 \pm 0.07 \%$ and without fertiliser $6.40 \pm 0.11 \%$, respectively).

Thus it may be concluded that the use of fertilisers does not have a notable influence on the ash content in biomass of grasses.

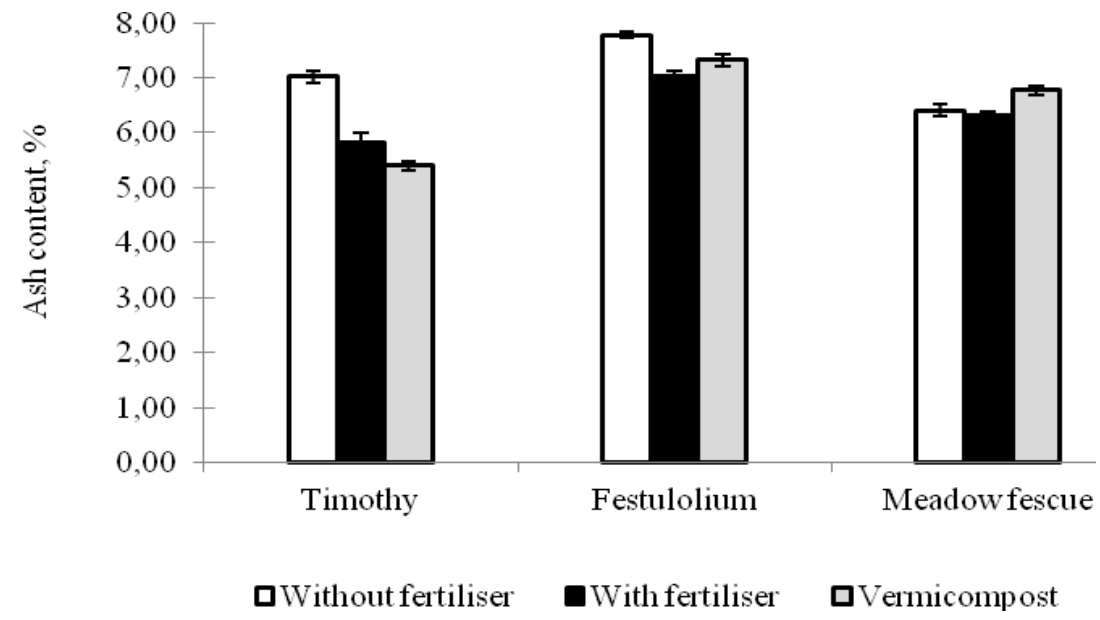

Figure 5: Comparison between average ash content and fertiliser types on grass biomass.

\section{Conclusions}

a. The data acquired show that energy grass biomass has high ash content, therefore it would be useful to produce pellets from grass biomass mixed with wood, since it would reduce ash content.

b. Analysis of the information obtained shows the lowest ash content in grass biomass treated with vermicompost. The lowest festulolium and meadow fescue ash content indicators were recorded for samples treated with $\mathrm{N}$ fertiliser, whereas timothy ash content was the lowest in samples treated with vermicompost. The lowest ash content among grasses was following: timothy $-5.91 \%$, festulolium $-7.15 \%$, and meadow fescue $-6.38 \%$.

c. Research indicated close, negative linear correlation between the grass biomass ash content and $\mathrm{N}$ fertiliser norms.

d. Research allows concluding that application of fertilisers does not leave significant influence on ash content.

\section{Acknowledgement}

This research was supported by the grant of the Ministry of Agriculture of the Republic of Latvia, Agreement No. 2013/86. 


\section{References}

[1] Directive 2009/28/ec of the european parliament and of the council of 23 April 2009 Online. http://eurlex.europa.eu/LexUriServ/LexUriServ.do? uri=Oj:L:2009:140:0016:0062:en:PDF1

[2] Lewandowski, I. \& Schmidt, U., Nitrogen, energy and land use efficiencies of miscanthus, reed canary grass and triticale as determined by the boundary line approach. Agriculture, Ecosystems \& Environment 112, pp. 335-346, 2006.

[3] Finell, M., Arshadi, M. \& Gref, R., Carbohydrate composition in delayed harvested reed canary grass. Biomass \& Bioenergy, 35(3), pp. 1097-1102, 2011.

[4] McKendry, P., Energy production from biomass (part 3): Gasification technologies. Bioresource Technology, 83(1), pp. 55-63, 2001.

[5] Dale, V.H., Kline, K.L., Wright, L.L, Perlack, R.D., Downing, M. \& Graham, R.L., Interactions among bioenergy feedstock choices, landscape dynamics, and land use. Ecological Applications 21, pp. 1039-1054, 2011.

[6] McKendry, P., Energy production from biomass (part 2): conversion technologies. Bioresource Technology 83, pp. 47-54, 2002.

[7] Beringer, T., Lucht, W. \& Schaphoff, S., Bioenergy production potential of global biomass plantations under environmental and agricultural constraints. GCB Bioenergy 3, pp. 299-312, 2011.

[8] Adamovičs, A., Dubrovskis, V., Plūme, I., Jansons, Ā., Lazdiņa, D. \& Lazdiňš, A., Biomasas izmantošanas ilgtspējības kritēriju pielietošana un pasākumu izstrāde (Criteria for biomass use sustainability and development of measures), Vides projekti, Rīga, pp. 125-159, 2009.

[9] Humphreys, M.O., The contribution of conventional plant breeding to forage crop improvement. Conventional and novel methodologies for plant improvement, Canada, pp. 97-98, 1997.

[10] Gutmane, I.\& Adamovich, A., Productivity and persistency of Festulolium and Lolium $\times$ boucheanum swards. Permanent and temporary grassland. Grassland Science in Europe, Vol. 12, pp. 59-62, 2007.

[11] Vuckovic S., Simic A., Eric, P., Cupina B., Petrovic R., Stojanovic I., Stanisavljevic, R. \& Vuckovic M., Relationships between forage yield and quality of perennial ryegrass and different rates of nitrogen fertilizer. Grassland Science in Europe, Vol. 8, Pleven, pp. 198-199, 2003.

[12] Gierus M., Jahns U., Wulfes R., Wiermann C. \& Taube F., Forage quality and yield increments of intensive managed grassland in response to combined sulphur-nitrogen fertilization. Acta Agriculturae Scandinavica, Soil and Plant Science, Vol. 55, pp. 264-274, 2005.

[13] Nesheim, L. \& Bronstad I., Yield and winter hardiness of Festulolium (Festuca $\times$ Lolium) in Norway. Grassland Science in Europe, vol.5, Denmark, pp. 238-240, 2000.

[14] Platače, R. \& Adamovičs, A., Energy crop pellet combustion ability. Research for rural development, Jelgava, pp. 50-55, 2012. 
[15] Tardenaka, A. \& Spince, B., Characterization of fuel granules and briquettes produced from fine-dispersed wastewood. An International conference Eco-Balt, Riga, pp. 37-38, 2006.

[16] Evaluation of the combustion characteristics of four perennial energy crops (arundo donax, cynara cardunculus, miscanthus $\mathrm{x}$ giganteus and panicum virgatum). Online http://www.cres.gr/bioenergy_chains/files/pdf/ Articles/10-Rome\%200E1_1.pdf

[17] Codling, E.E., Chaney, R.L. \& Sherwell, J. Poultry litter ash as a potential phosphorus source for agricultural crops. Journal of Environmental Quality, 31, pp, 954-961, 2002.

[18] Insaam, H., Franke-Whittle, I.H., Knapp, B.A. \& Plank R., Use of wood ash and anaerobic sludge for grassland fertilization: Effects on plants and microbes. Die Bodenkultur, 60(2), pp. 39-50, 2009.

[19] Tilvikiene, V., Kadžiuliene, Z. \& Dabkevičius, Z., The evaluation of tall fescue, cocksfoot and reed canary grass as energy crops for biogas production. Grassland Science in Europe, Vol. 15, Duderstadt, pp. 304-306, 2010. 